\title{
The overexpression of SOX2 affects the migration of human teratocarcinoma cell line NT2/D1
}

\author{
DANIJELA DRAKULIC ${ }^{1}$, JELENA MARJANOVIC VICENTIC ${ }^{1}$, \\ MARIJA SCHWIRTLICH ${ }^{1}$, JELENA TOSIC ${ }^{1,2}$, ALEKSANDAR KRSTIC ${ }^{1,3}$, \\ ANDRIJANA KLAJN ${ }^{1}$ and MILENA STEVANOVIC ${ }^{1}$ \\ ${ }^{1}$ Institute of Molecular Genetics and Genetic Engineering, University of \\ Belgrade, Vojvode Stepe 444a, P.O. BOX 23, 11010 Belgrade, Serbia \\ ${ }^{2}$ Center for Integrative Genomics, University of Lausanne, \\ Génopode, CH-1015 Lausanne, Switzerland \\ ${ }^{3}$ Systems Biology Ireland, University College Dublin, \\ Belfield, D4, Dublin, Ireland
}

Manuscript received on July 4, 2014; accepted for publication on October 14, 2014

\begin{abstract}
The altered expression of the SOX2 transcription factor is associated with oncogenic or tumor suppressor functions in human cancers. This factor regulates the migration and invasion of different cancer cells. In this study we investigated the effect of constitutive SOX2 overexpression on the migration and adhesion capacity of embryonal teratocarcinoma NT2/D1 cells derived from a metastasis of a human testicular germ cell tumor. We detected that increased SOX2 expression changed the speed, mode and path of cell migration, but not the adhesion ability of NT2/D1 cells. Additionally, we demonstrated that SOX2 overexpression increased the expression of the tumor suppressor protein p53 and the HDM2 oncogene. Our results contribute to the better understanding of the effect of SOX2 on the behavior of tumor cells originating from a human testicular germ cell tumor. Considering that NT2/D1 cells resemble cancer stem cells in many features, our results could contribute to the elucidation of the role of SOX 2 in cancer stem cells behavior and the process of metastasis.
\end{abstract}

Key words: adhesion, HDM2, migration, p53, SOX2, wound healing.

\section{INTRODUCTION}

Metastases are the major cause of mortality in patients with cancer (Steeg and Theodorescu 2008). The metastatic process is a complex, multistage process that includes invasion of cancer cells into surrounding tissue, the entrance of these cells into lymphatic and/or blood vessels, their survival in the bloodstream, their departure from the vessels

Correspondence to: Milena Stevanovic

E-mail: milenastevanovic@imgge.bg.ac.rs and the progressive growth of the tumor at a distant site (Steeg 2006, Goubran et al. 2014, Svokos et al. 2014). Literature data indicate that initial phases of metastasis require a wide spectrum of migration and invasion mechanisms (Friedl and Wolf 2003). Besides a role in metastasis, cell migration plays a central role in a variety of biological processes, such as embryo implantation, embryogenesis, morphogenesis, neurogenesis, and angiogenesis (Chernoivanenkoa et al. 2013). 
The SOX2 transcription factor is responsible for the regulation of two distinct and opposing functions: stem cell maintenance and differentiation (Graham et al. 2003, Wegner 2010). Moreover, a number of literature data indicate that altered expression of this transcription factor is associated with oncogenic (Bass et al. 2009, Gangemi et al. 2009, Bae et al. 2010, Leung et al. 2010, Lu et al. 2010, Basu-Roy et al. 2012, Girouard et al. 2012, Rudin et al. 2012, Herreros-Villanueva et al. 2013, Pham et al. 2013, Tang et al. 2013, Wang et al. 2014) or tumor suppressor (Otsubo et al. 2008, Wu et al. 2013) roles in human cancers. It has also been postulated that SOX2 may be involved in the maintenance of cancer stem cells (CSCs) (Liang et al. 2013). These cells, identified in various human malignancies (Ignatova et al. 2002, Al-Hajj et al. 2003, Dontu et al. 2003, Matsui et al. 2004, Fang et al. 2005, Hermann et al. 2007, Prince et al. 2007, Eramo et al. 2008, Levina et al. 2008, Zhang et al. 2008), are undifferentiated, characterized by a high tumorigenic and self-renewal capacity, activation of pluripotency genes (Oct4, SOX2, Nanog), unlimited proliferation, predisposition to differentiate into all the cell phenotypes of the parental tumor and multi-drug resistance (Liang et al. 2013, Zimmerer et al. 2013).

NT2/D1 is a well characterized human embryonal carcinoma (EC) cell line which was derived from a metastasis of a human testicular germ cell tumor (Andrews 1998). This cell line represents malignant counterparts of embryonic stem (ES) cells and resembles ES cells in morphology, antigen expression patterns, biochemistry, developmental potential and gene regulation (Andrews 1984). Considering that literature data suggest that ES/EC cells are similar to CSCs (Ben-Porath et al. 2008, Muller et al. 2008, Kim et al. 2010), NT2/D1 cells represent an adequate model system for studying, not only cancer cells of the testicular germ cell tumor, but also CSCs.

Recent data have demonstrated that SOX2 regulates the migration and invasion of different cancer cells (Han et al. 2012, Li et al. 2013, Wang et al. 2014, Yang et al. 2014). However, the role of SOX2 in the behavior of cells of the human testicular germ cell tumor is largely unknown. Thus, determinations of the role of altered SOX2 expression in these tumor cells will contribute to a better understanding of the cancer metastasis molecular mechanisms of the testicular germ cell tumor. The aim of this study was to determine the effect of SOX2 overexpression on the migratory capabilities and cell-matrix adhesion capacity of embryonal carcinoma NT2/D1 cells by using SOX2 overexpressing NT2/D1 cell clones previously generated in our laboratory (Drakulic et al. 2012). We have shown that increased SOX2 expression influences cell migration, but not the adhesion of NT2/D1 cells to the matrix. Furthermore, in order to better understand the molecular mechanisms associated with SOX2 overexpression, we analyzed protein expression of tumor suppressor protein p53 and oncogene HDM2 (human homologue of murine double minute 2 (MDM2)) in SOX2 overexpressing cell clones.

We found that p53 expression was increased in G3 cell clone only, while HDM2 expression was elevated in both SOX2 overexpressing NT2/ D1 cell clones.

\section{MATERIALS AND METHODS}

\section{Cell Culture}

Human NT2/D1 cells (ATCC ${ }^{\circledR}$ CRL-1973 ${ }^{\mathrm{TM}}$ ), SOX2-overexpressing NT2/D1 cell clones (F5 and G3) and empty vector-transfected control NT2/D1 cell clone (MOCK) were maintained in Dulbecco's Modified Eagle's medium (DMEM) supplemented with $10 \%$ fetal bovine serum (FBS), 4500 $\mathrm{mg} / \mathrm{L}$ glucose, $2 \mathrm{mmol} / \mathrm{L}$ L-glutamine (all from Invitrogen ${ }^{\mathrm{TM}}$ ) at $37^{\circ} \mathrm{C}$ in $10 \% \mathrm{CO}_{2}$ as previously described (Andrews 1984). SOX2-overexpressing NT2/D1 cell clones (F5 and G3) were obtained by stable transfection of NT2/D1 cells with a pcDNA3.1/SOX2 construct (containing full-length 
human SOX2 cDNA (Stevanovic et al. 1994)) and selection, using G418 (Drakulic et al. 2012). Empty vector-transfected control NT2/D1 cell clone (MOCK) was generated by stable transfection of NT2/D1 cells with a pcDNA3.1 expression vector and selection, using G418.

\section{IMMUNOCYTOCHEMISTRY}

Upon being plated on coverslips, cells were fixed in 4\% paraformaldehyde (PFA) for $20 \mathrm{~min}$ at room temperature (RT). Cells were permeabilized in $0.2 \%$ Triton X-100 and blocked in 10\% normal goat serum, $1 \%$ bovine serum albumin (BSA) and $0.1 \%$ Triton X-100 in PBS for $1 \mathrm{~h}$ at RT. Primary antibodies were diluted in PBS containing 1\% BSA and $0.1 \%$ Triton $\mathrm{X}-100$ and incubated overnight at $4^{\circ} \mathrm{C}$ as follows: rabbit polyclonal against SOX2 (Active Motif, 39824, diluted 1:1000) and mouse monoclonal anti $\alpha$-Tubulin (Calbiochem, CP06, diluted 1:100). Coverslips were washed in $0.1 \%$ Triton X-100 prepared in PBS (PBT) and incubated with anti-mouse guinea-pig secondary antibodies conjugated with Alexa FluorH 594 (InvitrogenTM, diluted 1:500 in 1\%BSA-PBT) for $1 \mathrm{~h}$ at RT. The antiSOX2 antibody was first labeled with biotinylated goat anti-rabbit IgG (Vector, Burlingame) for $1 \mathrm{~h}$ at RT in 1\% BSA, followed by FITC-streptavidin (Jackson ImmunoResearch, diluted 1:1000 in PBS) for $1 \mathrm{~h}$ at RT. Nuclei were stained with $0.1 \mathrm{mg} / \mathrm{ml}$ diamino phenylindole (DAPI; Sigma-Aldrich). Images were taken by a Leica TCS SP8 confocal microscope applying the Leica Microsystems LAS AF-TCS SP8 software (Leica Microsystems).

SCRATCH-Wound HEALING AsSAY

NT2/D1, MOCK and SOX2-overexpressing NT2/ D1 cell clones were grown to the confluent cell monolayer on glass coverslips or a plastic surface previously coated with $0.1 \%$ gelatin solution prepared in $1 x P B S$. Following $18-24 \mathrm{~h}$ incubation, the confluent cell monolayer was scratched with a $200 \mu \mathrm{l}$ tip. Floating cells were washed and cells were incubated in a fresh growing medium. Cell migration was monitored with the DM IL LED Inverted Microscope (Leica) for $24 \mathrm{~h}$ or with the Leica TCS SP8 confocal microscope using time-lapse imaging for $20 \mathrm{~h}$ with the application of $\mathrm{CO}_{2} / \mathrm{O}_{2}$ and temperature cage controllers (OKOLAB).

The Leica Microsystems LAS AF-TCS SP8 software was used to capture and analyze wound closure pictures (4 images per hour).

The cell migration distance $6 \mathrm{~h}$ and $12 \mathrm{~h}$ after scratches had been made was measured from at least three independent experiments. For each experiment, distance was measured for 30-60 cells.

The mode of cell migration into the gap was analyzed by counting single cells in 3-4 different parts of the wounded area from a minimum of three independent experiments.

The path of cell movement of cell clones and controls was determined from the cell migration tracks from three independent experiments. For each cell clone and control the path was analyzed from 10 single cell trajectories during $12 \mathrm{~h}$ (for all cell clones) and $20 \mathrm{~h}$ (for control only). In order to quantify cell path, binary codes were used (for the single cell with linear movement a value of 0 was given, while for cells with chaotically movement a value of 1 was given).

Cell-Matrix AdHesion Assay

The adhesion ability of SOX2-overexpressing cell clones and control cells was analyzed using ninety-six well plates coated with Matrigel (Becton Dickerson). Binding to nonspecific adhesive surfaces was blocked by $2 \%$ BSA(Sigma-Aldrich) in DMEM for $1 \mathrm{~h}$ at $37^{\circ} \mathrm{C}$. Cells were seeded at a density of 0.5 $\times 10^{5}$ cells/well in DMEM supplemented with $0.1 \%$ BSA. After 30 minutes the cells were gently washed three times with $1 \mathrm{xPBS}$ and the number of attached cells was determined using 3-(4,5-dimethylthiazol2yl)-2,5-diphenyltetrazolium bromide (MTT) assay. MTT solution was added to cell cultures at a final concentration of $1 \mathrm{mg} / \mathrm{ml}$ and cells were incubated 
for $2 \mathrm{~h}$ at $37^{\circ} \mathrm{C}$. Subsequently, the medium was removed and the cells were lysed in DMSO. The conversion of MTT to formazan by metabolically viable cells was monitored by microplate reader at a wavelength of $620 \mathrm{~nm}$. The tests were done in triplicate and repeated in 4 independent experiments.

REVERSE - TRANSCRIPTASE - PCR (RT-PCR) ANALYSIS

The total RNA from SOX2-overexpressing cell clones and control cells was isolated using the TRIReagent (Ambion) according to the manufacturer's instructions. Isolated RNA was treated with DNase I using the DNA-free ${ }^{\mathrm{TM}}$ kit (Ambion) and subjected to cDNA synthesis. $1 \mu \mathrm{g}$ of the total RNA was reversely transcribed using the High Capacity cDNA Reverse Transcription Kit (Applied Biosystems) according to the manufacturer's protocol. The synthesized cDNAs were amplified with primers specific for $p 53, H D M 2$ and GAPDH. $P 53$ was amplified with primers: 5 '-CCC CTC CTG GCC CCT GTC ATC TTC-3' (forward) and 5'- GCA GCG CCT CAC AAC CTC CGT CAT3' (reverse) (Yang et al. 2007); HDM2 with primers: 5'- CCC AAG ACA AAG AAG AGA GTG TGG-3 (forward) and 5'- CTG GGC AGG GCT TAT TCC TTT TCT-3' (reverse) (Frum et al. 2009) and GAPDH (glyceraldehyde 3-phosphate dehydrogenase) with: 5'-GCC TCA AGA TCA TCA GCA ATG C-3' (forward) and 5'-CCA CGA TAC CAA AGT TGT CAT GG-3' (reverse) (Drakulic et al. 2012). The expression of GAPDH was used to normalize levels of the total RNA used in assays. PCR reactions were performed in $20 \mu \mathrm{l}$ reactions using the KAPA 2G Fast HotStart Ready Mix (Kapa Biosystems). All samples were denatured $2 \mathrm{~min}$ at $95^{\circ} \mathrm{C}$ and then cycled at $95^{\circ} \mathrm{C}$ for $15 \mathrm{~s}, 60^{\circ} \mathrm{C}(G A P D H) / 61^{\circ} \mathrm{C}(H D M 2) / 68^{\circ} \mathrm{C}$ (p53) for $15 \mathrm{~s}$ and $72^{\circ} \mathrm{C}$ for $15 \mathrm{~s}$, for 30 cycles, with reaction aliquots taken at 25 and 30 cycles.

\section{WESTERN BLOT ANALYSIS}

Whole cell lysates were prepared from NT2/D1 cells, MOCK and SOX2-overexpressing NT2/D1 cell clones by briefly rinsing cells with ice-cold
PBS and then extracted in ice-cold Lysis buffer (1\% Triton $\mathrm{X}-100,50 \mathrm{mmol} / \mathrm{L}$ Tris- $\mathrm{HCl}(\mathrm{pH} 7.5)$, $250 \mathrm{mmol} / \mathrm{L} \mathrm{NaCl}, 5 \mathrm{mmol} / \mathrm{L}$ EDTA and protease inhibitor cocktail (Roche Diagnostics $\mathrm{GmbH}$ )). Proteins were quantified by Bradford protein assay (Bio-Rad Laboratories). Samples were separated by SDS-PAGE on $10 \%$ resolving gel and then electrotransferred onto the Immobilon-P Transfer Membrane (Millipore). After blocking with 5\% nonfat milk at $4{ }^{\circ} \mathrm{C}$ overnight, membranes were incubated for $1 \mathrm{~h}$ at RT with the following primary antibodies: mouse antibody against p53 (Gene Spin, DO1, diluted 1:1000), mouse antibody against MDM2 (Santa Cruz, sc-965, diluted 1:1000) and mouse monoclonal anti GAPDH (Abcam, 9484, diluted 1:5000). Finally, the membranes were incubated for $1 \mathrm{~h}$ at RT with the horseradish peroxidase-conjugated anti-mouse secondary antibodies (Amersham Biosciences, diluted 1:10000). Immunoreactive bands were detected by chemiluminescence (Immobilion substrate, Millipore).

\section{STATISTICAL ANALYSIS}

Statistical analysis was performed on a minimum of three independent experiments. Data were analyzed using the SPSS software. Values of $P \leq 0.05$ were considered significant.

\section{RESULTS}

OVEREXPRESSION OF SOX2 IN SOX2-OVEREXPRESSING NT2/D1 CELL CLONES

SOX2-overexpressing NT2/D1 cell clones (F5 and G3), used in this study, have previously been described in our previous work (Drakulic et al. 2012). We revealed that the overall SOX2 expression at the mRNA level in F5 and G3 cell clones increased approximately 1.7- and 3.1-fold, respectively, as compared to the parental NT2/ D1 cells. SOX2 protein overexpression in F5 and G3 cell clones, as compared to the parental cell line, was confirmed by the Western blot analysis (Drakulic et al. 2012). In order to analyze 
migratory and cell-matrix adhesion abilities of these cell clones, our first goal was to determine SOX2 protein expression at a single cell level by immunocytochemical analysis. MOCK NT2/D1 cell clone and parental NT2/D1 cells were used as controls (Fig. 1). Punctuate nuclear localization of SOX2 was detected in all the tested cell populations (Fig. 1, B, E, H and K) with varying intensity. In F5 and G3 cell clones the intensity of SOX2 signals detected in nuclei was higher in comparison to signals in the nuclei of the MOCK cell clone or parental cells. Additionally, no difference in the level of SOX2 expression between NT2/D1 and the MOCK cell clone was detected (Fig. 1, B and E). A higher intensity of SOX2 signals detected in nuclei of the G3 cell clone, when compared to parental cells, was in accordance with our recently published data (Klajn et al. 2014).

\section{SOX2 OVEREXPRESSION PROMOTES CELl MigRATION}

In order to analyze whether SOX2 overexpression influences the migration capability of embryonal carcinoma cells we performed the classical scratch wound healing assay (Liang et al. 2007, Matsumoto et al. 2012, Morani et al. 2014, Zhou et al. 2014). The migration of the cells into the wound area was monitored throughout a $24 \mathrm{~h}$ time window (Fig. 2). At the end of this period we detected that F5 and G3 cells had almost closed the wound (Fig. 2, F and H), whereas the control cells had not filled the wounded area within the same time frame (Fig. 2, B and D).

In order to measure the dynamics of cell movement into the scratched area we applied timelapse imaging throughout a $20 \mathrm{~h}$ time window. The first differences in cell migration between SOX2 overexpressing cell clones and control cells were obvious $6 \mathrm{~h}$ after the scratches had been made. At that point in time approximately $75 \%$ of $\mathrm{F} 5$ and $88 \%$ of G3 cells had migrated more than $80 \mu \mathrm{m}$ from their initial positions into the wounded area (Fig. 3, Panel I). At the same time a statistically significantly smaller percentage of control cells had crossed the same distance (38\% and $28 \%$ of NT2/ D1 and MOCK cells, respectively). Additionally, cell migration in the cell-free region was measured $12 \mathrm{~h}$ following the formation of the wounded area (Fig. 3, Panel I). When the threshold was set to $200 \mu \mathrm{m}$, significant differences in cell movement between cell clones and control cells were observed. Approximately 23\% and 39\% of F5 and G3 cells, respectively, migrated more than $200 \mu \mathrm{m}$ while approximately $7 \%$ of control cells covered this distance within the same time period.

The results obtained (Fig. 2 and 3, Panel I) revealed that, within the same time window, F5 and G3 cells migrated a greater distance when compared to control cells. Additionally, the results indicate that G3 cells migrated significantly faster in comparison to F5 cells. Since no differences in cell migration were detected between the parental and MOCK cells, only NT2/D1 cells are hereinafter presented as the control.

The next step was to investigate whether SOX2 overexpression could change the mode of cell migration into the scratched area. We detected that control cells migrated into the wound collectively, in groups comprising several cells. However, in F5 and G3 cell clones we observed a tendency to the single cell migration considering that we detected more single cells in the wounded area when compared to the controls (representative images of wound recovery of F5 and G3 cell clones and control are presented in Fig. 3, Panel IIA). The average number of single F5 (24 cells/gap) and G3 cells (41 cells/gap) migrating into the scratch area $6 \mathrm{~h}$ after the wound had been made was significantly higher than that of the control cells (on average 14 cells/gap) (Fig. 3, Panel IIB). The results imply that SOX2 overexpression influences the mode of migration causing a switch from cohesive to single cell motility.

We further analyzed whether SOX2 overexpression could modulate the path of cell movement by studying the cell migration tracks. Bearing in mind that F5 and G3 cells migrated 

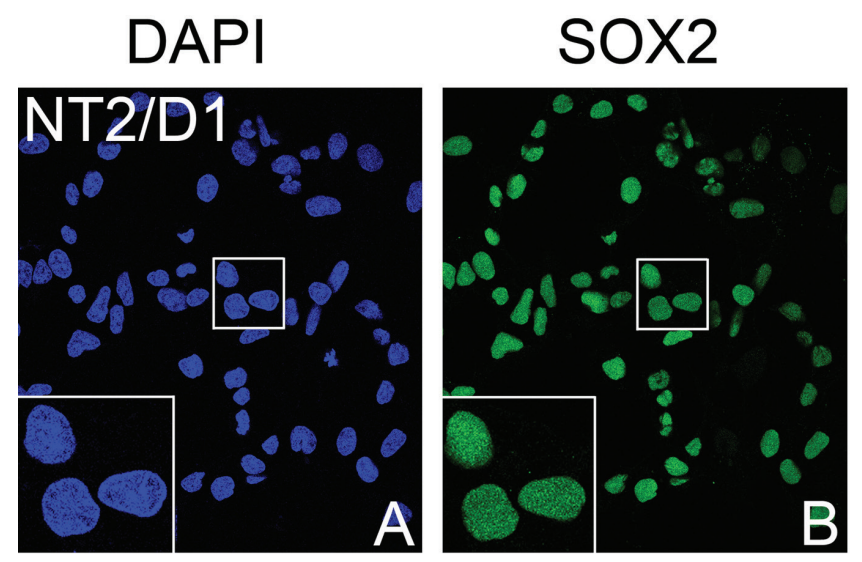

\section{$\alpha-$ TUBULIN}
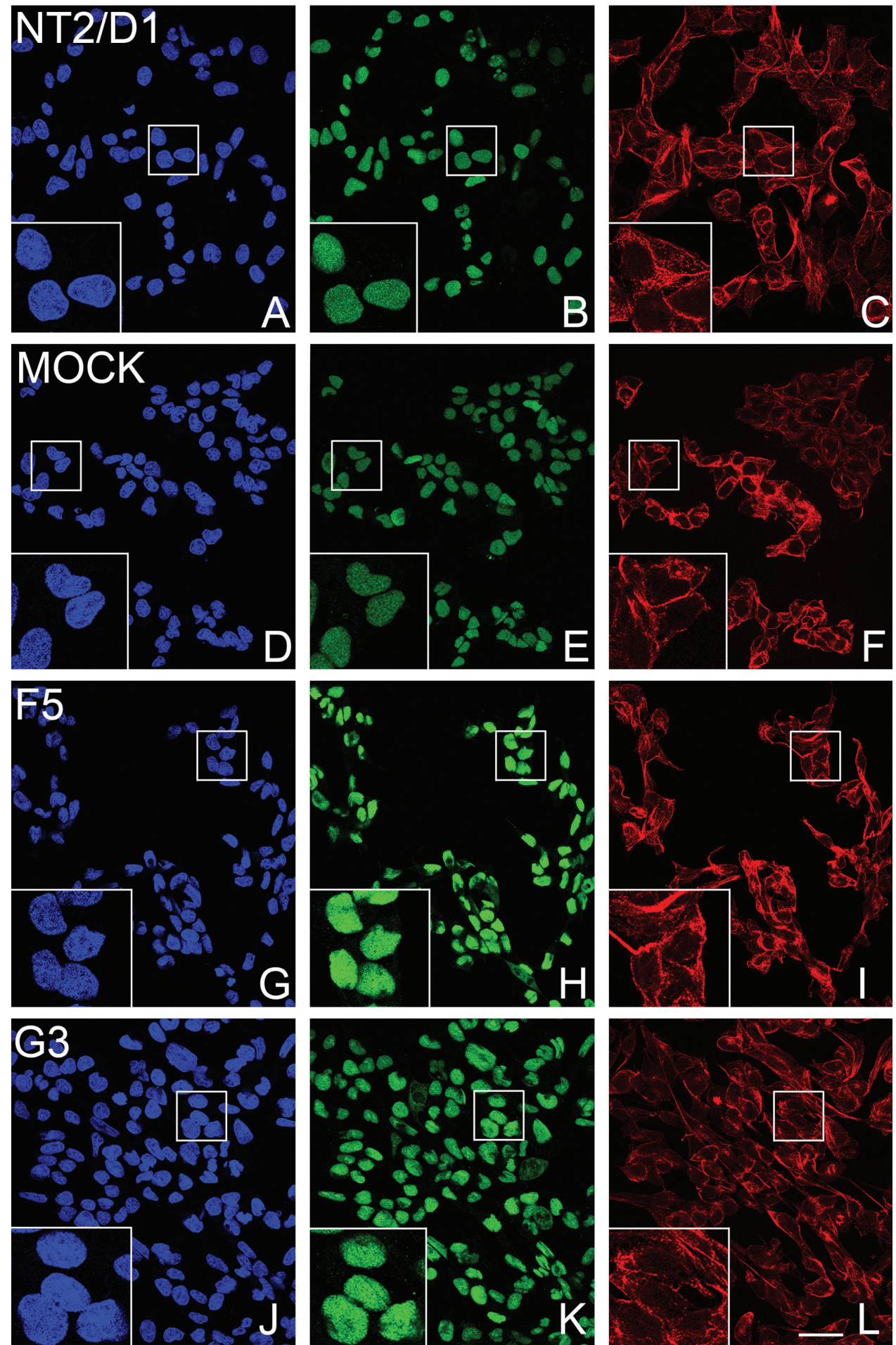

Figure 1 - Elevated SOX2 protein expression in SOX2-overexpressing NT2/D1 cell clones. Immunocytochemical analysis of SOX2 expression in NT2/D1 (B), MOCK (E), F5 (H) and G3 (K) cells. Cells were visualized by staining microtubules with $\alpha$-Tubulin (C, F, I, L). Boxed regions in A-L are enlarged in the same figures. Cell nuclei were co-stained with DAPI (A, D, G, J). Scale bar: 50 $\mu$ m. NT2/ D1 = NT2/D1 cells; MOCK = empty vector-transfected control NT2/D1 cell clone; F5, G3 = SOX2-overexpressing NT2/D1 cell clone. 

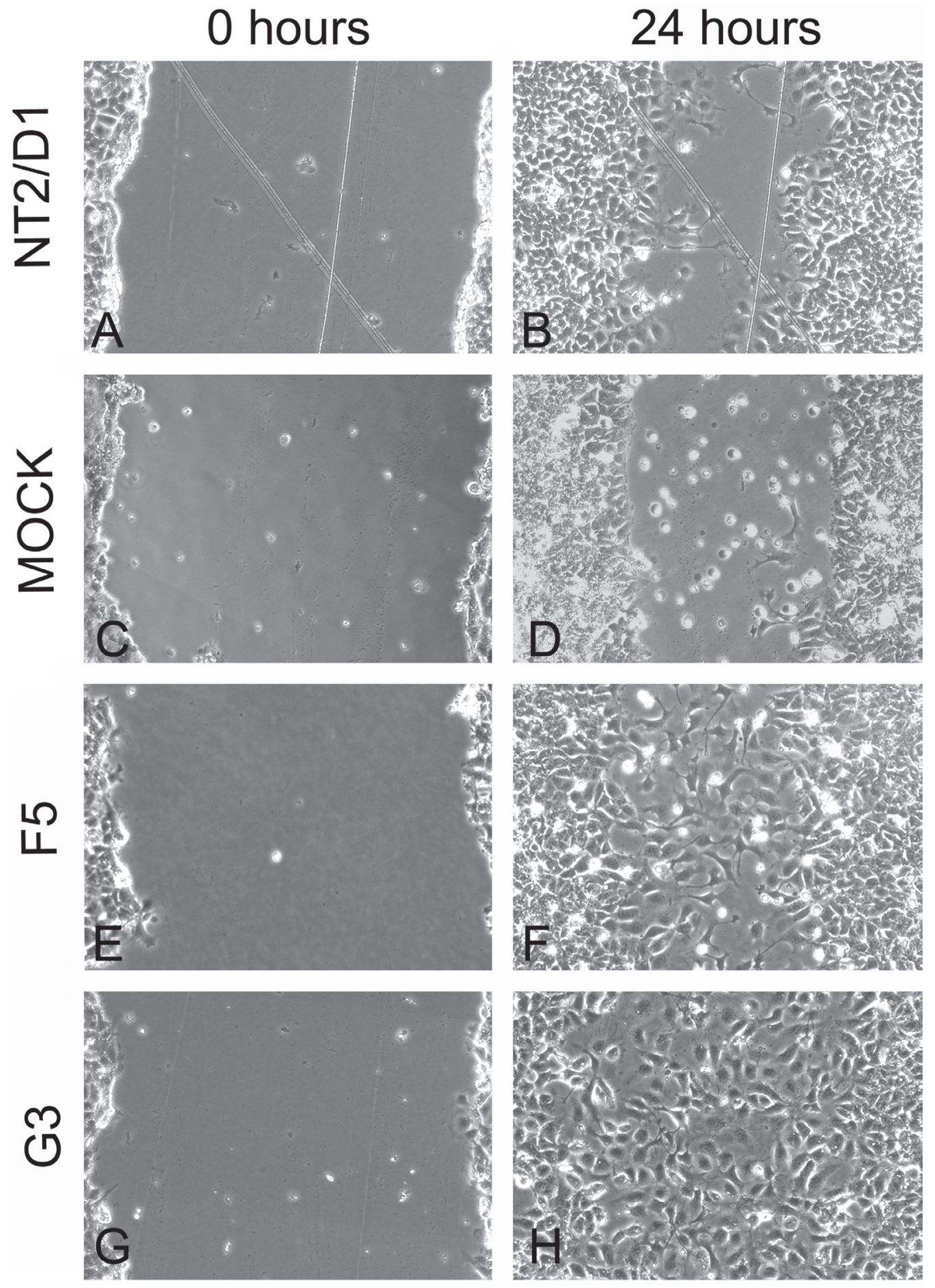

Figure 2 - Effect of SOX2 overexpression on cell wound recovery. Nearly confluent cell monolayers of NT2/D1, MOCK, F5 and G3 cells were scratched and wound recovery was monitored throughout a $24 \mathrm{~h}$ time window. Representative phase contrast images of 3 independent wound closure experiments show that F5 (E, F) and G3 (G, H) cells almost closed the gap while control cells did not fill the wounded area in this time window $(\mathrm{A}-\mathrm{D})$. Cell migration was monitored with the DM IL LED Inverted Microscope (Leica) using 10x objective. NT2/D1 = NT2/D1 cells; MOCK = empty vector-transfected control NT2/D1 cell clone; F5, G3 = SOX2overexpressing NT2/D1 cell clone. 

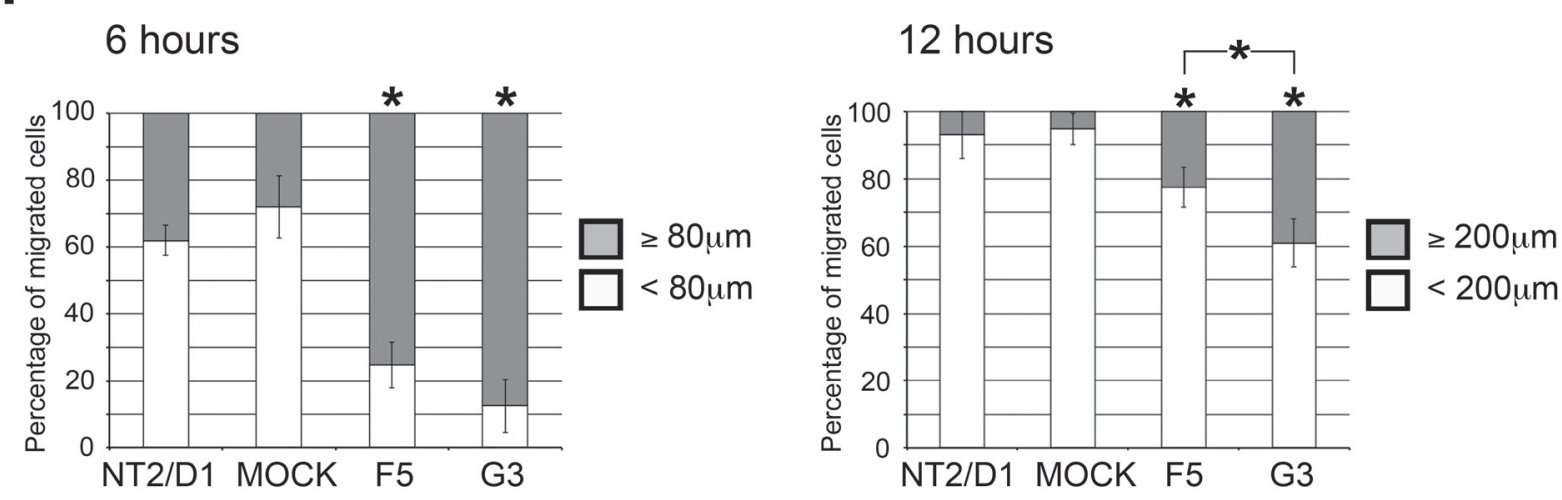

II A

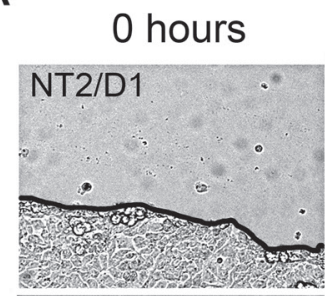

6 hours
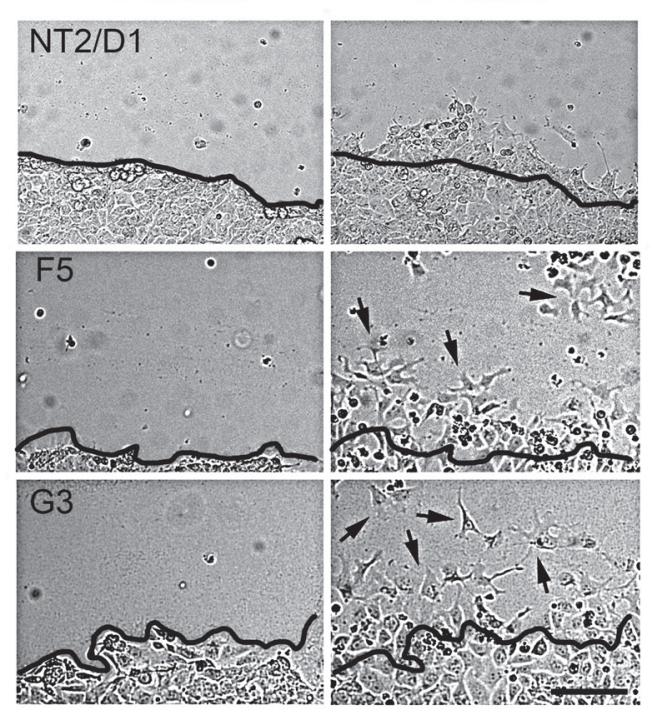

B

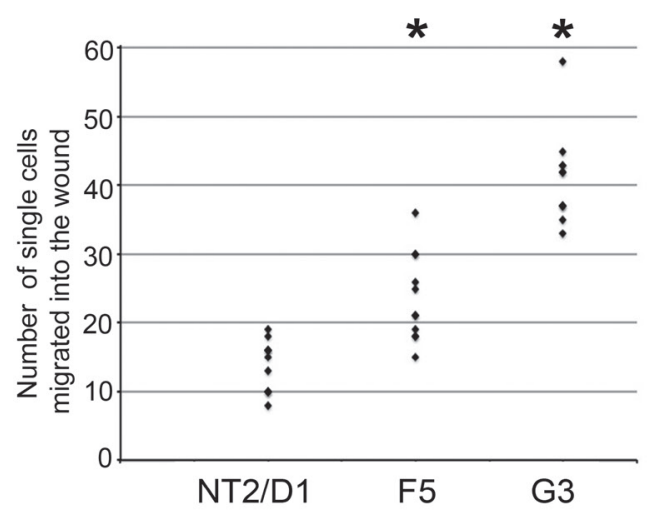

III

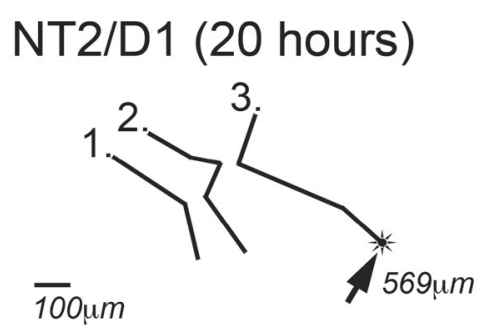

F5 (12 hours)

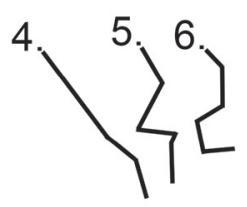

G3 (12 hours)

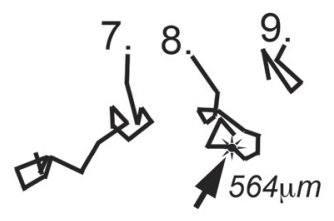

Figure 3 - Effect of SOX2 overexpression on NT2/D1 cell migration. Cell motility was monitored using time-lapse microscopy. Panel I. The migration distance of cells from their initial positions was measured after 6h (left) and 12h (right). Panel II. Representative images (A) and graphs (B) comparatively show the mode of cell migration of NT2/D1, F5 and G3 cells 6h after the scratches had been made. Arrows indicate single cells in wounded area. Scale bar: $100 \mu \mathrm{m}$. Panel III. 3 representative cell migration trajectories were obtained during 12h (F5, G3) and 20h (NT2/D1) of time-lapse imaging of indicated cells. Arrows indicate exact distance of trajectories ( $569 \mu \mathrm{m}$ for cell 3 and $564 \mu \mathrm{m}$ for cell 8). NT2/D1 = NT2/D1 cells; MOCK= empty vectortransfected control NT2/D1 cell clone; F5, G3 = SOX2-overexpressing NT2/D1 cell clone. 
faster, the path of cell migration was observed within a $12 \mathrm{~h}$ time window for SOX2 overexpressing cell clones, and within a $20 \mathrm{~h}$ time window for NT2/D1 cells only. By analyzing the migratory trajectories of cells we calculated the percentage of SOX2 overexpressing and control cells that migrated linearly vs. chaotically (Fig. 3, Panel III). Our results revealed that the majority of G3 cells migrated chaotically (approximately 80\%). However, we detected that only a small percentage of control cells (approximately 10\%) within the $20 \mathrm{~h}$ time window moved chaotically, while the majority of them had a linear movement. The analysis of the approximately same path distances $(564 \mu \mathrm{m}$ and $569 \mu \mathrm{m}$ for G3 and NT2/D1, respectively) provided further evidence that G3 migrate, not just further and faster, but differently in comparison to control cells. However, no statistically significant difference was detected in the paths of movement between F5 cell clone (approximately 30\% of cells migrated chaotically) and NT2/D1 cells.

The presented results indicate that SOX2 overexpression in embryonal carcinoma NT2/D1 cells could influences the speed, mode and path of cell migration.

\section{SOX2 OVEREXPRESSION Did Not AFFECT CELl-MATRIX}

ADHESION

The ability of cancer cells to form metastasis depends on their ability to adhere to and degrade extracellular matrix. It has been demonstrated that cells which either do not adhere or adhere too tightly to the matrix are not able to move and invade (Walsh et al. 2009, Ranjan and Kalraiya 2013, Svokos et al. 2014). In order to assess the effects of SOX2 overexpression on adhesion capacity of NT2/D1 cells we performed in vitro testing using Matrigel. This attachment substrate, commonly used as basement membrane matrix, is rich in extracellular matrix proteins (Mullen 2004). Here we demonstrated that the number of adherent cells observed in F5 and G3 cell clones was not altered in a statistically significant way, when compared to MOCK and parental cells (Fig. 4). The obtained results indicate no difference in the cell-matrix adhesion ability between SOX2 overexpressing cell clones and controls.

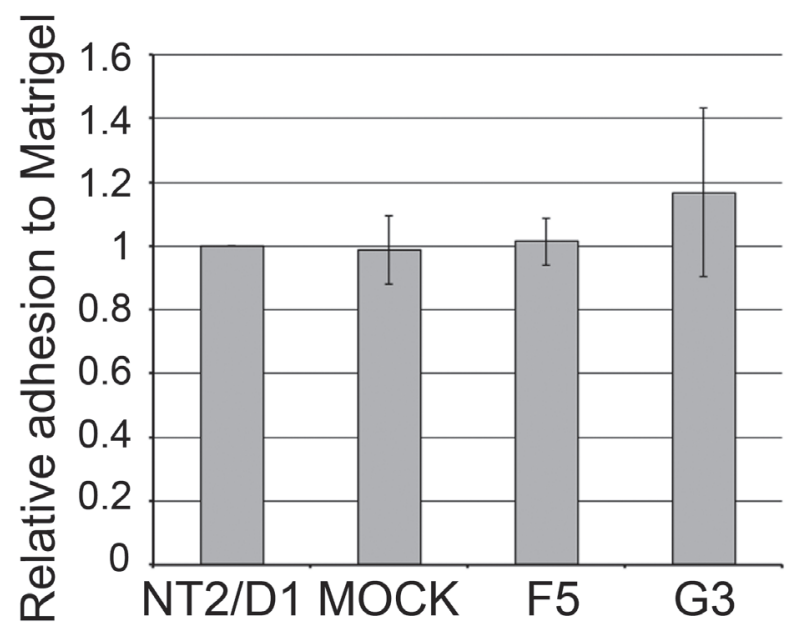

Figure 4 - Adhesion of cells to Matrigel. Cell adhesion was measured using the MTT test. Results are expressed as a fold of adhesion of parental NT2/D1 cells, which was set as 1 . Experiments were performed in triplicate and repeated four times. Data of independent experiments are presented in a histogram as the mean $\pm \mathrm{SD} . P \leq 0.05$ were considered as significant. NT2/D1 = NT2/D1 cells; MOCK = empty vectortransfected control NT2/D1 cell clone; F5 and G3 = SOX2overexpressing NT2/D1 cell clones.

\section{SOX2 OVEREXPRESSION ALTERED THE EXPRESSION}

PROFILE OF P53 AND HDM2

To evaluate whether SOX2 overexpression had modified the expression of tumor suppressor proteins and oncogenes we further tested the expression level of tumor suppressor protein p53 and its cellular regulator oncogene HDM2.

HDM2 and p53 protein expression in F5 and G3 cell clones and control cells was determined by the Western blot analysis (Fig. 5, Panel I). We demonstrated that the expression level of p53 was increased approximately 2.8-fold in the G3 cell clone, when compared to the parental cell line. At the same time relative quantification of $\mathrm{p} 53$ protein expression did not reveal statistically significant 
differences between the F5 cell clone and NT2/ D1 cells. The results of relative quantification revealed that HDM2 expression was increased approximately 2.1- and 2.8-fold in F5 and G3 cells, respectively, in comparison to parental cells.

Additionally, we analyzed p53 and HDM2 expression at the mRNA level in F5 and G3 cell clones and control cells by semiquantitative RT-PCR analysis (representative images are presented in Fig. 5, Panel II). Elevated level of $p 53$ mRNA was revealed in G3 cell clone only. We detected that HDM2 expression was increased in both cell clones when compared to control cells. These data are in line with results obtained by Western blot analysis (Fig. 5, Panel I).

The results obtained imply that the modulation of SOX2 expression could alter the expression of tumor suppressor protein $\mathrm{p} 53$, as seen in the G3 cell clone, and oncogene HDM2, as seen in both SOX2 overexpressing cell clones.

\section{DISCUSSION}

Testicular germ cell tumors, heterogeneous group of neoplasms, are the most common malignancy in males between 15 and 34 years of age (Bahrami et al. 2007, Chieffi and Chieffi 2013). Here we demonstrate that SOX2 overexpression influences the migratory potential of NT2/D1 cells, derived from the metastasis of a human testicular germ cell tumor. These results are in accordance with the results obtained with different cancer cells, such as ovarian cancer, breast cancer, glioma, lung cancer, colorectal cancer cells and laryngeal squamous cell carcinoma cell line (Hussenet et al. 2010, Lu et al. 2010, Alonso et al. 2011, Simoes et al. 2011, Han et al.2012, Lou et al. 2013, Yang et al.2014). In contrast to our result, in the human bladder carcinoma cell line ECV304 ectopic expression of SOX2, OCT4 and NANOG compromised cell motility (Zhou et al. 2013), while SOX2 knockdown in U343-MG glioma cell line decreased migration in vitro, but increased the migratory capacity of cancer cells in the brain in vivo (Oppel et al. 2011).
Our results imply that SOX2 overexpression does not only increase cell motility, but influences the mode of cell migration. Namely, in F5 and G3 cell clones we observed a tendency to switch from cohesive to single cell motility. Literature data have demonstrated that during dissemination, tumor cells may migrate as individual cells or in a group (Friedl and Wolf 2003). In many tumors, both types of dissemination can be detected (Alexandrova 2008). Results obtained by Giampieri et al. suggest that changes in the mode of cell motility affect metastasis (Giampieri et al. 2009). Namely, they demonstrated that TGF $\beta 1$ switched cells from cohesive to single cell motility in breast cancer cells. Additionally, they found that the mode of migration governs the haematogenous or lymphatic spread: single cell motility increased the ability of cells to enter into the bloodstream while cohesive motility reduced cell entrance into the bloodstream but allowed the lymphatic spread (Giampieri et al. 2009). Considering these results we could postulate that SOX2 overexpression in the human testicular embryonal carcinoma NT2/D1 cell line promotes the generation of blood-borne metastasis. Moreover, we found that $\mathrm{G} 3$ cells which moved in a gap as single cells migrated faster into the cell free region when compared to parental cells. This is in accordance with the results obtained by Giampieri et al. who demonstrated that movement in a group was significantly slower than single cell motility (Giampieri et al. 2009). Interestingly, we found that SOX2 overexpression in the G3 cell clone altered the path of cell migration, but not in the F5 SOX2 overexpressing cell clone when compared to parental cells. Considering that F5 and G3 cell clones are different in the level of overall SOX2 overexpression (Drakulic et al. 2012), we speculate that the observed differences in the path of cell migration might be the results of SOX2 dosedependent effects. Literature data indicate that different cellular processes, such as neurogenesis, eye development and differentiation could be 

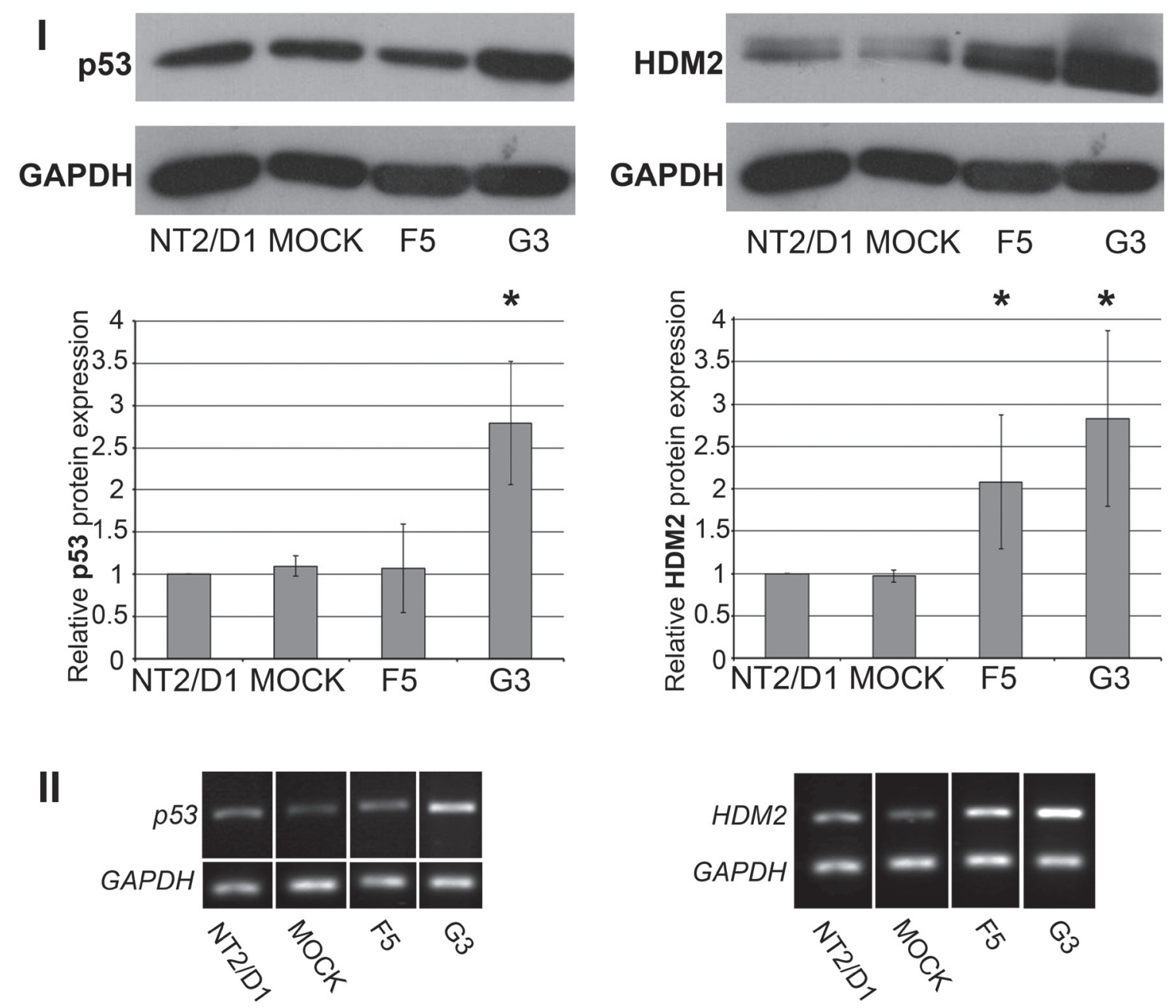

Figure 5 - Profile of p53 and HDM2 expression in SOX2-overexpressing NT2/D1 cell clones. Panel I Proteins expression was detected by the Western Blot using p53, HDM2 and GAPDH -specific antibodies. At least three independent experiments were performed and one representative blot was shown. Bands were digitalized, quantified with the ImageJ software and normalized for GAPDH values. The relative p53 and HDM2 expression levels were calculated as a fold expression of parental NT2/D1 cells. A value of 1 was given to the relative p53 and HDM2 expression levels in parental cells. Data were presented as the means \pm SD. $P \leq 0.05$ were considered as significant. Panel II mRNA expression was detected by semi-quantitative RT-PCR using primers specific for $p 53, H D M 2$ and $G A P D H$. Three independent experiments were performed and one representative image was shown. NT2/D1 = NT2/D1 cells; MOCK = empty vector-transfected control NT2/D1 cell clone; F5 and G3 = SOX2-overexpressing NT2/D1 cell clones.

SOX2 dose-dependent (Avilion et al. 2003, Bylund et al. 2003, Graham et al. 2003, Ellis et al. 2004, Ferri et al. 2004, Bani-Yaghoub et al. 2006, Taranova et al. 2006, Cavallaro et al. 2008). Additionally, it has been postulated that dose-dependent effects of SOX2 are important not only for in vivo development but also for in vitro reprogramming (Yamaguchi et al. 2011).
The metastatic potential of cancer cells is influenced not only by the migratory potential but by adhesion ability as well. We demonstrated that SOX2 overexpression did not change cell-matrix adhesion capacity of NT2/D1 cells. Our results are not in agreement with the results obtained in breast and pancreatic cancer cells which have revealed 
that strong suppression of the endogenous SOX2 promoter activity induces anchorage-independent growth in breast cancer (Stolzenburg et al. 2012) while SOX2 overexpression in pancreatic cancer cells decreases the expression of epithelial markers E-Cadherin and ZO-1, which is involved in cell adhesion (Herreros-Villanueva et al. 2013). On the basis of the results obtained we could postulate that an elevated SOX2 level in human testicular embryonal carcinoma cells may influence only certain steps involved in the generation of metastasis. Additionally, our results imply that the effects of SOX2 on cellmatrix adhesion could be cell context specific.

Interestingly, we found that the expression of tumor suppressor p53, as well as the HDM2 oncogene was increased in the G3 cell clone. It is possible that the observed increases in p53 and HDM2 expression are the results of direct interactions between SOX2 and the regulatory regions of these genes. Several ChIP-seq studies have identified that SOX2, alone or in a complex with different transcription factors, occupies promoter and/or enhancer regions of p53 and MDM2 genes (Loh et al. 2006, Marson et al. 2008, Fang et al. 2011, Lodato et al. 2013). Further studies are needed to reveal if SOX2 directly regulates expression of $\mathrm{p} 53$ and HDM2.

The p53 tumor suppressor plays an essential role in the regulation of cell cycle progression, DNA repair, apoptosis and senescence, preventing the growth and survival of damaged and abnormal cells (Sablina et al. 2003). Recent studies suggest that the effects of $\mathrm{p} 53$ on the processes of migration and invasion are cell context-dependent (Hollstein et al. 1991, Vogelstein et al. 2000, Lewis et al. 2005, Moskovits et al. 2006, Ku et al. 2007, Morton et al. 2008, Mukhopadhyay et al. 2010). In line with our results, the accumulation of $\mathrm{p} 53$ protein in mouse embryonic fibroblasts has been revealed in the condition of forced expression of SOX2 ( $\mathrm{Li}$ et al. 2009, Banito and Gil 2010). In this study we detected an increased migratory potential in the
G3 cell clone with an elevated level of p53. These results are in contrast with results demonstrating that the overexpression of exogenous p53 in mouse fibroblasts decreased cell migration into the wound in vitro (Alexandrova et al. 2000). On the other hand, it has been reported that the loss of p53 function correlates with decreased cell migration in human foreskin fibroblasts, human colon and lung carcinoma cell lines, as well as in mouse normal fibroblasts from the lung and the spleen, peritoneal macrophages and keratinocytes (Sablina et al. 2003). Furthermore, the expression of exogenous p53 in the p53-deficient human lung carcinoma H1299 cell line stimulated cell migration (Sablina et al. 2003). Further studies are needed to determine whether SOX2 overexpression in the NT2/D1 cell line promotes migration dependently/independently of the p53 pathway. On the other hand, we detected no differences in $\mathrm{p} 53$ expression between the F5 cell clone and control cells. We speculate that different levels of SOX2 expression could have a diverse effect on p53 expression in NT2/D1 cells.

HDM2 is an oncogene which is overexpressed in numerous human cancers, including breast, lung, colon, pancreas, lymphomas, leukemias, sarcomas and primary glioblastomas (Oliner et al. 1992, McCann et al. 1995, Biernat et al. 1997, Momand et al. 1998, Rayburn et al. 2005, Veerakumarasivam et al. 2008, Wade et al. 2013, Sheng et al. 2014). Numerous studies have demonstrated that MDM2 overexpression is associated with enhanced cell invasion, migration, greater metastatic potential and resistance to chemotherapeutic agents and radiation (Rayburn et al. 2009).

Therefore, we could postulate that both, SOX2 overexpression, and upregulation of HDM2 expression, contribute to the increased migratory capability detected in F5 and G3 cell clones.

MDM2 regulates p53 expression by three mechanisms: by forming a complex with p53 and by blocking its capability to activate transcription; through its E3 ubiquitin ligase activity that 
ubiquitinates p53 and stimulates its degradation; and by involvement in the nuclear export of p53 (Jones et al. 1995, Montes de Oca Luna et al. 1995, Bottger et al. 1997, Haupt et al. 1997, Kubbutat et al. 1997, Lane and Hall 1997, Midgley and Lane 1997, Thut et al. 1997, Michael and Oren 2003).

In G3 cell clone HDM2 overexpression did not lead to decreased p53 expression. A possible explanation may be that SOX2 could directly/ indirectly activate the transcription of the HDM2 inhibitor which binds HDM2 in the p53-binding pocket and blocks the interaction of HDM2 with $\mathrm{p} 53$, leading to the stabilization of $\mathrm{p} 53$. Literature data has revealed that the incubation of the colon cancer line HCT116 with the inhibitor of MDM2 led to an increase in the p53 and MDM2 levels (Vassilev et al. 2004).

In summary, our results further elucidate the effect of SOX2 overexpression in cancer cells derived from a human testicular germ cell tumor. Importantly, this cell line has features similar to CSCs. Considering the significant role of CSCs in tumor progression, the determination of SOX2 function in cells that resemble CSCs may be important for further elucidation of the biology of these cells as well as for the diagnosis and development of a therapeutic strategy for cancer therapy. Additional investigations are needed to clarify the SOX2 involvement in the regulation of the migration and invasiveness of cancer cells. This could provide new perspectives in the effort to inhibit metastasis.

\section{ACKNOWLEDGMENTS}

This work was supported by the Ministry of Education, Science and TechnologicalDevelopment, Republic of Serbia (Grant No. 173051) and by the Serbian Academy of Sciences and Arts (Project: "Studying the molecular mechanisms involved in maintaining pluripotency and differentiation of stem cells", No F 24). We thank Prof Roberto Mantovani for generously providing anti-p53 and
anti-SOX2 antibodies. We would like to thank Prof Peter W. Andrews (University of Sheffield, UK) for human NT2/D1 cells.

\section{RESUMO}

A expressão alterada do fator de transcrição SOX2 está associada com funções oncogênicas ou de supressão de tumor em cânceres humanos. Este fator regula a migração e invasão de diferentes células cancerosas. Neste estudo, investigamos o efeito da superexpressão da SOX2 constitutiva na migração e capacidade de adesão de células de teratocarcinoma embrionário NT2/D1 derivadas de uma metástase de tumor humano testicular de células germinativas. Nós detectamos que a expressão aumentada de SOX2 mudou a velocidade, o modo e a via de migração celular, mas não a habilidade de adesão das células NT2/ D1. Além disso, nós demonstramos que a superexpressão de SOX2 aumentou a expressão da proteína supressora tumoral p53 e do oncogene HMD2. Nossos resultados contribuem para uma melhor compreensão do efeito de SOX2 no comportamento de células tumorais originárias de um tumor humano de células germinativas testiculares. Considerando que as células NT2/D1 se assemelham a células-tronco cancerosas em vários aspectos, nossos resultados podem contribuir para a elucidação do papel de SOX2 no comportamento de células-tronco cancerosas e no processo de metástase.

Palavras-chave: adesão, HDM2, migração, p53, SOX2, cicatrização de feridas.

\section{REFERENCES}

Al-Haju M, Wicha MS, Benito-Hernandez A, Morrison SJ AND ClARKe MF. 2003. Prospective identification of tumorigenic breast cancer cells. Proc Natl Acad Sci U S A 100: 3983-3988.

Alexandrova A, Ivanov A, Chumakov P, Kopnin B AND VASILIEV J. 2000. Changes in p53 expression in mouse fibroblasts can modify motility and extracellular matrix organization. Oncogene 19: 5826-5830.

ALEXANDROVA AY. 2008. Evolution of cell interactions with extracellular matrix during carcinogenesis. Biochemistry (Mosc) 73: 733-741.

AlONSO MM ET AL. 2011. Genetic and epigenetic modifications of Sox 2 contribute to the invasive phenotype of malignant gliomas. PLoS One 6: e26740. 
ANDREWS PW. 1984. Retinoic acid induces neuronal differentiation of a cloned human embryonal carcinoma cell line in vitro. Dev Biol 103: 285-293.

ANDREWS PW. 1998. Teratocarcinomas and human embryology: pluripotent human EC cell lines. Review article. APMIS 106: 158-167; discussion 167-158.

AVILION AA, Nicolis SK, PEVNY LH, PEREZ L, Vivian N AND LOVELL-BADGE R. 2003. Multipotent cell lineages in early mouse development depend on SOX2 function. Genes Dev 17: 126-140.

BAE KM ET AL. 2010. Expression of pluripotent stem cell reprogramming factors by prostate tumor initiating cells. J Urol 183: 2045-2053.

Bahrami A, Ro JY AND AYala AG. 2007. An overview of testicular germ cell tumors. Arch Pathol Lab Med 131: 1267-1280.

BANI-YAgHOUB MetaL. 2006. Role of Sox 2 in the development of the mouse neocortex. Dev Biol 295: 52-66.

BANITO A AND GIL J. 2010. Induced pluripotent stem cells and senescence: learning the biology to improve the technology. EMBO Rep 11:353-359.

BASS AJ ET AL. 2009. SOX2 is an amplified lineage-survival oncogene in lung and esophageal squamous cell carcinomas. Nat Genet 41: 1238-1242.

Basu-Roy U, Seo E, Ramanathapuram L, Rapp TB, Perry JA, ORKIN SH, MANSUKHANI A AND BASILICO C. 2012 Sox 2 maintains self renewal of tumor-initiating cells in osteosarcomas. Oncogene 31: 2270-2282.

Ben-Porath I, Thomson MW, Carey VJ, Ge R, Bell GW, REGEV A AND WeINBERG RA. 2008. An embryonic stem cell-like gene expression signature in poorly differentiated aggressive human tumors. Nat Genet 40: 499-507.

BieRnAT W, Kleihues P, YoneKaWA Y AND OHgaKi H. 1997. Amplification and overexpression of MDM2 in primary (de novo) glioblastomas. J Neuropathol Exp Neurol 56: 180-185.

BotTger A, BotTger V, SPARKS A, LiU WL, HowARD SF AND LANE DP. 1997. Design of a synthetic Mdm2-binding mini protein that activates the p53 response in vivo. Curr Biol 7: 860-869.

Bylund M, ANDERsson E, Novitch BG AND MuHr J. 2003. Vertebrate neurogenesis is counteracted by Sox1-3 activity. Nat Neurosci 6: 1162-1168.

CAVALlARO M ET AL. 2008. Impaired generation of mature neurons by neural stem cells from hypomorphic Sox2 mutants. Development 135: 541-557.

ChernoivanenkoA IS, Minin AA AND Minin AA. 2013. Role of Vimentin in Cell Migration. Russian Journal of Developmental Biology 44: 144-157.

CHIEFFI P AND CHIEFFI S. 2013. Molecular biomarkers as potential targets for therapeutic strategies in human testicular germ cell tumors: an overview. J Cell Physiol 228: 1641-1646.

Dontu G, ABDallah WM, Foley JM, Jackson KW, Clarke MF, KAWAMURA MJ AND WICHA MS. 2003. In vitro propagation and transcriptional profiling of human mammary stem/progenitor cells. Genes Dev 17: 1253-1270.
DRAKULIC D, KRSTIC A AND STEVANOVIC M. 2012. Establishment and initial characterization of SOX2overexpressing NT2/D1 cell clones. Genet Mol Res 11: $1385-1400$.

Ellis P, FAgAn BM, Magness ST, HutTon S, TARANOVA O, Hayashi S, Mcmahon A, RaO M AND PeVny L. 2004 SOX2, a persistent marker for multipotential neural stem cells derived from embryonic stem cells, the embryo or the adult. Dev Neurosci 26: 148-165.

Eramo A, Lotti F, Sette G, Pilozzi E, Biffoni M, Di Virgilio A, Conticello C, Ruco L, Peschle C And DE MARIA R. 2008. Identification and expansion of the tumorigenic lung cancer stem cell population. Cell Death Differ 15: 504-514.

FAng D, NGUYen TK, LEISHEAR K, FinKo R, KulP AN, HotZ S, VAN Belle PA, Xu X, Elder DE AND Herlyn M. 2005. A tumorigenic subpopulation with stem cell properties in melanomas. Cancer Res 65: 9328-9337.

FANG XETAL. 2011. The SOX2 response program in glioblastoma multiforme: an integrated ChIP-seq, expression microarray, and microRNA analysis. BMC Genomics 12: 11.

FERRI AL ET AL. 2004. Sox2 deficiency causes neurodegeneration and impaired neurogenesis in the adult mouse brain. Development 131: 3805-3819.

FRIEDL P AND WOLF K. 2003. Tumour-cell invasion and migration: diversity and escape mechanisms. Nat Rev Cancer 3: 362-374.

Frum R, Ramamoorthy M, Mohanraj L, Deb S AND Deb SP. 2009. MDM2 controls the timely expression of cyclin A to regulate the cell cycle. Mol Cancer Res 7: 1253-1267.

GANGemi RM, Griffero F, MARUbBi D, PERERA M, CAPrA MC, Malatesta P, Ravetti GL, Zona GL, Daga A AND CORTE G. 2009. SOX2 silencing in glioblastoma tumorinitiating cells causes stop of proliferation and loss of tumorigenicity. Stem Cells 27: 40-48.

Giampieri S, ManNing C, Hooper S, Jones L, Hill CS AND SAHAI E. 2009. Localized and reversible TGFbeta signalling switches breast cancer cells from cohesive to single cell motility. Nat Cell Biol 11: 1287-1296.

GIROUARD SD, LAGA AC, MIHM MC, SCOLYER RA, THOMPSON JF, ZHAN Q, WIDLUND HR, LEE CW AND MURPHY GF. 2012. SOX2 contributes to melanoma cell invasion. Lab Invest 92: 362-370.

Goubran HA, Kotb RR, STAKIW J, EMARA ME AND BuRnOUF T. 2014. Regulation of tumor growth and metastasis: the role of tumor microenvironment. Cancer Growth Metastasis 7: 9-18.

Graham V, Khudyakov J, Ellis P And PeVny L. 2003. SOX2 functions to maintain neural progenitor identity. Neuron 39: 749-765.

Han X, Fang X, Lou X, Hua D, Ding W, Foltz G, Hood L, YUAN Y AND LIN B. 2012. Silencing SOX2 induced mesenchymal-epithelial transition and its expression predicts liver and lymph node metastasis of CRC patients. PLoS One 7: e41335.

Haupt Y, MaYa R, KaZAZ A AND OREN M. 1997. Mdm2 promotes the rapid degradation of p53. Nature 387: 296-299. 
Hermann PC, Huber SL, Herrler T, Aicher A, Ellwart JW, GuBA M, BRUnS CJ AND HEESCHEN C. 2007. Distinct populations of cancer stem cells determine tumor growth and metastatic activity in human pancreatic cancer. Cell Stem Cell 1: 313-323.

Herreros-Villanueva M ET AL. 2013. SOX2 promotes dedifferentiation and imparts stem cell-like features to pancreatic cancer cells. Oncogenesis 2: e61.

HollsteIn M, SidRanSKY D, VOGELSTEIN B AND HaRris CC. 1991. p53 mutations in human cancers. Science 253: 49-53.

HUSSENET T ET AL. 2010. SOX2 is an oncogene activated by recurrent 3q26.3 amplifications in human lung squamous cell carcinomas. PLoS One 5: e8960.

IgNATOVA TN, KuKEKOV VG, LAYWELl ED, Suslov ON, VRIONIS FD AND STEINDLER DA. 2002. Human cortical glial tumors contain neural stem-like cells expressing astroglial and neuronal markers in vitro. Glia 39: 193-206.

Jones SN, RoE AE, DONEHOWER LA AND BRAdLEy A. 1995. Rescue of embryonic lethality in Mdm2-deficient mice by absence of p53. Nature 378: 206-208.

Kim J, Woo AJ, Chu J, Snow JW, Fujiwara Y, Kim CG, CANTOR AB AND ORKIN SH. 2010. A Myc network accounts for similarities between embryonic stem and cancer cell transcription programs. Cell 143: 313-324.

Klajn A, Drakulic D, Tosic M, PaVkovic Z, Schwirtlich M AND Stevanovic M. 2014. SOX2 Overexpression Affects Neural Differentiation of Human Pluripotent NT2/D1 Cells. Biochemistry (Mosc) 79: 1172-1182.

Ku TK, NGUYen DC, Karaman M, GiLl P, HaCia JG AND CROWE DL. 2007. Loss of p53 expression correlates with metastatic phenotype and transcriptional profile in a new mouse model of head and neck cancer. Mol Cancer Res 5: 351-362.

KubButat MH, Jones SNAND Vousden KH. 1997. Regulation of p53 stability by Mdm2. Nature 387: 299-303.

LANE DP AND HALL PA. 1997. MDM2--arbiter of p53's destruction. Trends Biochem Sci 22: 372-374.

Leung EL, Fiscus RR, Tung JW, Tin VP, Cheng LC, SiHoE AD, FINK LM, MA Y AND WONG MP. 2010. Non-small cell lung cancer cells expressing CD44 are enriched for stem cell-like properties. PLoS One 5: e14062.

LEVINA V, MARRANGONi AM, DEMARCo R, GORELIK E AND LOKSHIN AE. 2008. Drug-selected human lung cancer stem cells: cytokine network, tumorigenic and metastatic properties. PLoS One 3: e3077.

LEWIS BC, KLIMSTRA DS, SOCCI ND, XU S, Koutcher JA AND VARMUS HE. 2005. The absence of p53 promotes metastasis in a novel somatic mouse model for hepatocellular carcinoma. Mol Cell Biol 25: 1228-1237.

Li H, Collado M, Villasante A, Strati K, Ortega S, Canamero M, Blasco MA And Serrano M. 2009. The Ink4/Arf locus is a barrier for iPS cell reprogramming. Nature 460: 1136-1139.

LiX, XU Y, CHEN Y, CHEN S, JiAX, SUnT, LIU Y, Li X, XIANG RAND LI N. 2013. SOX2 promotes tumor metastasis by stimulating epithelial-to-mesenchymal transition via regulation of WNT/ beta-catenin signal network. Cancer Lett 336: 379-389.
LIANG CC, PARK AY AND GUAN JL. 2007. In vitro scratch assay: a convenient and inexpensive method for analysis of cell migration in vitro. Nat Protoc 2: 329-333.

LIANG S, FURUHASHI M, NAKANE R, NAKAZAWA S, GOUDARZI H, HAMADA J AND IIZASA H. 2013. Isolation and characterization of human breast cancer cells with SOX2 promoter activity. Biochem Biophys Res Commun 437: 205-211.

Lodato MA, NG CW, WAMstad JA, Cheng AW, Thai KK, FRAENKEL E, JAENISCH R AND BOYER LA. 2013. SOX2 co-occupies distal enhancer elements with distinct POU factors in ESCs and NPCs to specify cell state. PLoS Genet 9: e1003288.

LOH YH ET AL. 2006. The Oct4 and Nanog transcription network regulates pluripotency in mouse embryonic stem cells. Nat Genet 38: 431-440.

LOU X, HAN X, Jin C, Tian W, Yu W, Ding D, Cheng L, Huang B, JIANG H AND LIN B. 2013. SOX2 targets fibronectin 1 to promote cell migration and invasion in ovarian cancer: new molecular leads for therapeutic intervention. OMICS 17: 510-518.

Lu Y, FutTner C, Rock JR, Xu X, Whitworth W, Hogan BL AND ONAITIS MW. 2010. Evidence that SOX2 overexpression is oncogenic in the lung. PLoS One 5: e11022.

MARSON A ET AL. 2008. Connecting microRNA genes to the core transcriptional regulatory circuitry of embryonic stem cells. Cell 134: 521-533.

Matsui W, HufF CA, WANG Q, Malehorn MT, BARBer J, TANHeHCO Y, SMITH BD, CIVIN CI AND JONES RJ. 2004. Characterization of clonogenic multiple myeloma cells. Blood 103: 2332-2336.

Matsumoto M ET AL. 2012. Impacts of icodextrin on integrinmediated wound healing of peritoneal mesothelial cells. Life Sci 90: 917-923.

mcCann AH, Kirley A, Carney DN, Corbally N, Magee HM, KEATING G AND DERVAN PA. 1995. Amplification of the MDM2 gene in human breast cancer and its association with MDM2 and p53 protein status. Br J Cancer 71: 981985.

Michael D AND OREN M. 2003. The p53-Mdm2 module and the ubiquitin system. Semin Cancer Biol 13: 49-58.

MidGLEY CA AND LANE DP. 1997. p53 protein stability in tumour cells is not determined by mutation but is dependent on Mdm2 binding. Oncogene 15: 1179-1189.

Momand J, Jung D, WilczYnSKi S AND NiLAND J. 1998. The MDM2 gene amplification database. Nucleic Acids Res 26: 3453-3459.

Montes de Oca Luna R, Wagner DS And Lozano G. 1995. Rescue of early embryonic lethality in mdm2-deficient mice by deletion of p53. Nature 378: 203-206.

Morani F, Phadngam S, Follo C, Titone R, Thongrakard V, Galetto A, Alabiso O AND Isidoro C. 2014. PTEN deficiency and mutant p53 confer glucose-addiction to thyroid cancer cells: impact of glucose depletion on cell proliferation, cell survival, autophagy and cell migration. Genes Cancer 5: 226-239. 
Morton JP, Klimstra DS, Mongeau ME And Lewis BC. 2008. Trp53 deletion stimulates the formation of metastatic pancreatic tumors. Am J Pathol 172: 1081-1087.

Moskovits N, Kalinkovich A, BAR J, LAPIDOT T AND OREN M. 2006. p53 Attenuates cancer cell migration and invasion through repression of SDF-1/CXCL12 expression in stromal fibroblasts. Cancer Res 66: 10671-10676.

Mukhopadhyay UK, MoOney P, Jia L, Eves R, Raptis L AND MAK AS. 2010. Doubles game: Src-Stat3 versus p53PTEN in cellular migration and invasion. Mol Cell Biol 30: 4980-4995.

Mullen P. 2004. The use of Matrigel to facilitate the establishment of human cancer cell lines as xenografts. Methods Mol Med 88: 287-292.

MULLER FJ ET AL. 2008. Regulatory networks define phenotypic classes of human stem cell lines. Nature 455: 401-405.

Oliner JD, KinZler KW, Meltzer PS, George DL AND VOGELSTEIN B. 1992. Amplification of a gene encoding a p53-associated protein in human sarcomas. Nature 358: 80-83.

OpPel F, MUller N, SCHACKERT G, HENDRUSCHK S, MARTIN D, GEIGER KD AND TEMME A. 2011. SOX2-RNAi attenuates S-phase entry and induces RhoA-dependent switch to protease-independent amoeboid migration in human glioma cells. Mol Cancer 10: 137.

OTSUBO T, AKIYAMA Y, YANAGIHARA K AND YUASA Y. 2008. SOX2 is frequently downregulated in gastric cancers and inhibits cell growth through cell-cycle arrest and apoptosis. Br J Cancer 98: 824-831.

PHAM DL ET AL. 2013. SOX2 expression and prognostic significance in ovarian carcinoma. Int J Gynecol Pathol 32: 358-367.

Prince ME, Sivanandan R, KaCzorowski A, Wolf GT, Kaplan MJ, Dalerba P, Weissman IL, Clarke MF AND AILLES LE. 2007. Identification of a subpopulation of cells with cancer stem cell properties in head and neck squamous cell carcinoma. Proc Natl Acad Sci USA 104: 973-978.

RANJAN A AND KALRAIYA RD. 2013. alpha2,6 sialylation associated with increased beta 1,6-branched $\mathrm{N}$-oligosaccharides influences cellular adhesion and invasion. J Biosci 38: 867-876.

RAYBURN E, ZHANG R, HE J AND WANG H. 2005. MDM2 and human malignancies: expression, clinical pathology, prognostic markers, and implications for chemotherapy. Curr Cancer Drug Targets 5: 27-41.

RAYBURN ER, EZELL SJ AND ZHANG R. 2009. Recent advances in validating MDM2 as a cancer target. Anticancer Agents Med Chem 9: 882-903.

RUDIN CM ET AL. 2012. Comprehensive genomic analysis identifies SOX2 as a frequently amplified gene in smallcell lung cancer. Nat Genet 44: 1111-1116.

Sablina AA, Chumakov PM AND Kopnin BP. 2003. Tumor suppressor p53 and its homologue p73alpha affect cell migration. J Biol Chem 278: 27362-27371.
Sheng W, Dong M, Zhou J, Li X, LiU Q, Dong Q And LI F. 2014. The clinicopathological significance and relationship of Gli1, MDM2 and p53 expression in resectable pancreatic cancer. Histopathology 64: 523-535.

Simoes BM, PIVA M, IRIONDO O, COMAILLS V, LOPEZ-RUIZ JA, ZaBAlZA I, MieZA JA, ACINAS O AND ViVANCO MD 2011. Effects of estrogen on the proportion of stem cells in the breast. Breast Cancer Res Treat 129: 23-35.

STEEG PS. 2006. Tumor metastasis: mechanistic insights and clinical challenges. Nat Med 12: 895-904.

STEEG PS AND THEODORESCU D. 2008. Metastasis: a therapeutic target for cancer. Nat Clin Pract Oncol 5: 206219.

SteVAnovic M, ZufFardi O, Collignon J, LOVELl-Badge R AND GOODFELLOW P. 1994. The cDNA sequence and chromosomal location of the human SOX2 gene. Mamm Genome 5: 640-642.

StolzenburG S, Rots MG, Beltran AS, RivenBARK AG, YUAN X, QIAN H, STRAHL BD AND BLANCAFORT P. 2012. Targeted silencing of the oncogenic transcription factor SOX2 in breast cancer. Nucleic Acids Res 40: 6725-6740.

Svokos KA, SALHIA B AND TOMS SA. 2014. Molecular biology of brain metastasis. Int J Mol Sci 15: 9519-9530.

TANG XB, SHEN XH, LI L, ZHANG YF AND CHEN GQ. 2013 SOX2 overexpression correlates with poor prognosis in laryngeal squamous cell carcinoma. Auris Nasus Larynx 40: 481-486.

TARANOVA OV, Magness ST, FAGan BM, Wu Y, SURZENKO N, Hutton SR AND PEVny LH. 2006. SOX2 is a dose-dependent regulator of retinal neural progenitor competence. Genes Dev 20: 1187-1202.

THUT CJ, GOODRICH JA AND TJIAN R. 1997. Repression of p53-mediated transcription by MDM2: a dual mechanism. Genes Dev 11: 1974-1986.

VASSILEV LT ET AL. 2004. In vivo activation of the $\mathrm{p} 53$ pathway by small-molecule antagonists of MDM2. Science 303: 844-848.

VEERAKUMARASIVAM A ET AL. 2008. High-resolution arraybased comparative genomic hybridization of bladder cancers identifies mouse double minute 4 (MDM4) as an amplification target exclusive of MDM2 and TP53. Clin Cancer Res 14: 2527-2534.

Vogelstein B, LANE D AND LeVINE AJ. 2000. Surfing the p53 network. Nature 408: 307-310.

WADE M, LI YC AND WAHL GM. 2013. MDM2, MDMX and p53 in oncogenesis and cancer therapy. Nat Rev Cancer 13: 83-96.

Walsh N, Clynes M, Crown J and O'Donovan N. 2009. Alterations in integrin expression modulates invasion of pancreatic cancer cells. J Exp Clin Cancer Res 28: 140.

Wang X, Ji X, Chen J, Yan D, Zhang Z, Wang Q, Xi X AND FENG Y. 2014. SOX2 Enhances the Migration and Invasion of Ovarian Cancer Cells via Src Kinase. PLoS One 9: e99594.

Wegner M. 2010. All purpose Sox: The many roles of Sox proteins in gene expression. Int J Biochem Cell Biol 42: 381-390. 
Wu F, Ye X, Wang P, Jung K, Wu C, Douglas D, Kneteman N, BIGRAS G, MA Y AND LAI R. 2013. SOX2 suppresses the invasiveness of breast cancer cells via a mechanism that is dependent on Twist 1 and the status of SOX2 transcription activity. BMC Cancer 13: 317.

YAMAGUCHI S, HIRANO K, NAGATA S AND TADA T. 2011. SOX2 expression effects on direct reprogramming efficiency as determined by alternative somatic cell fate. Stem Cell Res 6: 177-186.

YANG G, XU Y, CHEN X AND Hu G. 2007. IFITM1 plays an essential role in the antiproliferative action of interferongamma. Oncogene 26: 594-603.

YANG N, Hui L, Wang Y, YANG H AND Jiang X. 2014. Overexpression of SOX2 promotes migration, invasion, and epithelial-mesenchymal transition through the Wnt/ beta-catenin pathway in laryngeal cancer Hep-2 cells. Tumour Biol 35(8): 7965-7973.
Zhang S, BALCh C, Chan MW, LAI HC, MATEI D, Schilder JM, YAN PS, HUANG TH AND NEPHEW KP. 2008. Identification and characterization of ovarian cancerinitiating cells from primary human tumors. Cancer Res 68: 4311-4320.

Zhou Q, GuI S, ZHOU Q AND WANG Y. 2014. Melatonin inhibits the migration of human lung adenocarcinoma A549 cell lines involving JNK/MAPK pathway. PLoS One 9: e101132.

ZHOU X, Li B, FAN H AND LIU Z. 2013. Control of regulatory T cells and $\mathrm{T}$ helper cells in human diseases: from bench to bedside. J Mol Cell Biol 5: 210-211.

Zimmerer RM, Korn P, Demougin P, KampManN A, KOKEMULler H, ECKARDT AM, GELlRICH NC AND TAVASSOL F. 2013. Functional features of cancer stem cells in melanoma cell lines. Cancer Cell Int 13: 78. 
